\title{
Effect of foliar application of potassium and its spray schedule on yield and yield parameters of sweet orange (Citrus sinensis Osbeck) cv. Jaffa
}

\author{
Vijay*, R. P. S. Dalal, B. S. Beniwal and Hemant Saini \\ Department of Horticulture, CCS Haryana Agricultural University, Hisar-125004 (Haryana), INDIA \\ *Corresponding author. E-mail: shotreturns@gmail.com
}

Received: August 25, 2016; Revised received: January 15, 2017; Accepted: April 22, 2017

\begin{abstract}
An investigation to evaluate the effect of foliar application of potassium and its spray schedule on yield and yield parameters in sweet orange cv. Jaffa was undertaken at experimental orchard, Department of Horticulture, CCS Haryana Agricultural University, Hisar during the year 2014-15. The results revealed that the foliar application of potassium nitrate at the rate of 2 and $4 \%$ and potassium sulphate at 1.5 and $3.0 \%$ significantly improved average fruit weight, fruit diameter, percentage of medium and large fruits, and fruit yield of sweet orange cv. Jaffa over control (water spray). The trend was vice-versa on the percentage of small fruits. The number of fruits per plant could not differ significantly due to various treatments. Among $\mathrm{K}$ sources and doses, foliar application of $\mathrm{KNO}_{3}$ at 4 $\%$ exhibited superiority over other treatments with respect to yield and yield parameters followed by $\mathrm{KNO}_{3}$ at lower dose $(2 \%)$ or $\mathrm{K}_{2} \mathrm{SO}_{4}$ at higher dose $(3 \%)$. Among various spray schedules, application of three sprays of $\mathrm{K}$ in the last week of April, May and August were found superior or at par in improving yield and yield parameters with 2 sprays in the last week of April and August. The fruit yield was recorded the highest $(76.90 \mathrm{~kg} / \mathrm{plant})$ with a combination of the foliar application of $\mathrm{KNO}_{3}$ at $4 \%$ and 2 sprays in the last week of April and August which was nonsignificant with $\mathrm{KNO}_{3}$ with an additional spray in the last week of May. The findings signify the importance of $\mathrm{K}$ spray in improving yield and yield parameters of sweet orange under semi-arid climatic conditions of north western India.
\end{abstract}

Keywords: Foliar application, Fruit yield, Potash, Spray schedule, Yield parameters

\section{INTRODUCTION}

Citrus possesses a share of $12.4 \%$ in fruit production of the country India (Saxena and Gandhi, 2014). Variable and small size fruit production is one of the main production constraints in citrus industry which results in poor economic return to the grower. To have more consumer acceptability, the fruit must have good quality and proper size. Medium to large fruit size increases fruit yield (Yadav et al., 2014) and fetches premium price in the market (Sangwan et al., 2008).

Foliar application of nutrients have gained importance in recent years to rectify the deficiencies of nutrients as sometimes soil application is not effective due to adaphic and environmental hazards. Availability of nutrients through foliar application is easy and quick to the plants. It has been found that foliar application of potassium after flowering increased fruit size of Valencia oranges (Miller and Hofman, 1988) and fruit yield of Citrus sinensis cv. Jaffa (Vijay et al., 2016).

The inadequacy of potassium is one of the most striking factors that regulate the size of fruit. Potassium is important in formation and functioning of proteins, fats, carbohydrates and chlorophyll and also in maintaining the balance of salts and water in plant cells (Abd-Allah, 2006). Potassium as a macro nutrient plays a regulatory role in many physiological and bio- chemical processes of plant including enzyme activation, protein synthesis, stomatal function, stabilization of internal $\mathrm{pH}$, photosynthesis, turgor related processes and transport of metabolites and extensibility that affects fruit size (Alva et al., 2006). Hence, potassium plays a key role in determining yield and yield parameters of fruit crops. Reports on the impact of $\mathrm{K}$ and time of its foliar application on yield and yield attributes of sweet orange are scarcely documented. The present investigation was thus carried out to generate information in this direction in sweet orange cv. Jaffa under the semi-arid conditions of north western India.

\section{MATERIALS AND METHODS}

The present investigation was conducted at experimental orchard of Department of Horticulture, CCS Haryana Agricultural University, Hisar during the year 2014-15. The experiment comprised of four treatments of $\mathrm{K}$ fertilizers and its rate of application viz. potassium nitrate at $2\left(\mathrm{~T}_{1}\right)$ and $4 \%\left(\mathrm{~T}_{2}\right)$, potassium sulphate at $1.5 \%\left(\mathrm{~T}_{3}\right)$ and $3.0 \%\left(\mathrm{~T}_{4}\right)$ which were compared with control $\left(T_{5}\right)$ i.e. water spray. There were three spray schedules i.e. $\mathrm{S}_{1}$ (two sprays in the last week of April and August), $S_{2}$ (two sprays in the last week of May and August) and $\mathrm{S}_{3}$ (three sprays in the last week of April, May and August). Forty five sweet orange 
cv. Jaffa trees having uniform size and vigour were selected for investigation. All the fifteen treatments were replicated thrice taking one plant as a single unit. Uniform cultural practices and plant protection measures were followed for these trees throughout the study period as per package of practices (Anonymous, 2013).

For measuring average fruit weight, five randomly selected fruits from different positions of the tree were picked and weighed on top pan electronic balance. The average fruit weight was calculated by dividing the total fruit weight by total number of fruits taken and expressed in gram (g). Fruit diameter was recorded with Digital Vernier's Calipers and average value was expressed in centimeters (cm). Grading of fruits was doneat the time of harvesting on the basis of diameter and categorized as large $(>7.0 \mathrm{~cm})$, medium $(6.0-7.0$ $\mathrm{cm})$ and small $(<6.0 \mathrm{~cm})$. Number of fruits per plant was counted at the time of harvesting and expressed as number of fruits per plant.Total yield per plant was recorded at harvest and expressed in $\mathrm{kg} /$ plant. Statistical analysis of data collected during the study was done at $5 \%$ level of significance in randomized block design as per procedure described by Panse and Sukhatme (1967).

\section{RESULTS AND DISCUSSION}

Effect on yield parameters: All the potassium treatments increased the fruit weight over control (Table 1) and it was also observed that there was an increase in fruit weight with an increase in potassium doses of $\mathrm{KNO}_{3}$ and $\mathrm{K}_{2} \mathrm{SO}_{4}$, irrespective of spray schedule. Out of various treatments $\mathrm{KNO}_{3} @ 4 \%$ gave maximum average fruit weight $(157.62 \mathrm{~g})$ followed by $3 \%$
$\mathrm{K}_{2} \mathrm{SO}_{4}$ (153.02g). Similarly, increased frequency of $\mathrm{K}$ sprays increased the fruit weight and maximum (153.10g) was found with three sprays during April, May and August followed by two sprays during April and August. The lowest fruit weight (149.15g) with two sprays of potassium during May and August may be due to the fact that in last week of May the fruits had already attained more than $50 \%$ of its size. Increase in fruit weight with potassium application might be due to the enhanced photosynthesis which leads to supply of more carbohydrates (Harold and George, 1966). Another probable cause could be the greater mobility of assimilates by potassium to the developing fruits which acted as strong metabolic sink. The more pronounced effect of $\mathrm{KNO}_{3}$ as compared to $\mathrm{K}_{2} \mathrm{SO}_{4}$ may be due to the additional supply of nitrogen which may further increase the efficiency of metabolic processes of plant and thus increases the growth of the plant and consequently increases the fruit weight. The increase in fruit weight with three sprays during April, May and August may be due to continuous supply of K to the developing fruits. Similar findings were obtained in mandarin citrus fruits by foliar application of $\mathrm{KNO}_{3}$ (a) $5 \%+2$, 4-D 20 ppm sprayed 6-8 weeks after flowering (Erner et al., 1993). Josan et al. (1995) reported similar results in lemon by foliar sprays of $10 \%$ $\mathrm{K}_{2} \mathrm{SO}_{4}$. Rattanpal et al. (2005) observed that fruit weight of Kinnow increased over control by foliar application of $\mathrm{KNO}_{3} @ 5 \%+2$, 4-D 20ppm when sprayed at 60 days after full bloom. Likewise, Hamza et al. (2012) reported that treatment with higher dose of $\mathrm{KNO}_{3}(8 \%) \times 3$ foliar applications proved most effective in improving average fruit weight as compared to lower dose of $\mathrm{KNO}_{3}(5 \%) \times 2$ foliar applica-

Table 1. Effect of foliar application of potassium and spray schedule on average fruitweight ( $\mathrm{g}$ ).

\begin{tabular}{|c|c|c|c|c|}
\hline \multirow{3}{*}{ Treatments } & \multicolumn{3}{|c|}{ Spray schedule } & \multirow[t]{2}{*}{ Mean } \\
\hline & $\mathrm{S}_{1}$ & $\mathrm{~S}_{2}$ & $\mathrm{~S}_{3}$ & \\
\hline & \multicolumn{3}{|c|}{ Weight of fruits $(\mathrm{g})$} & \\
\hline $\mathrm{T}_{1}: \mathrm{KNO}_{3} 2 \%$ & 153.43 & 150.46 & 154.69 & 152.86 \\
\hline $\mathrm{T}_{2}: \mathrm{KNO}_{3} 4 \%$ & 159.07 & 153.97 & 159.81 & 157.62 \\
\hline $\mathrm{T}_{3}: \mathrm{K}_{2} \mathrm{SO}_{4} 1.5 \%$ & 150.14 & 148.02 & 150.77 & 149.64 \\
\hline $\mathrm{T}_{4}: \mathrm{K}_{2} \mathrm{SO}_{4} 3 \%$ & 153.44 & 151.41 & 154.20 & 153.02 \\
\hline $\mathrm{T}_{5}$ : Control (water spray) & 145.68 & 145.91 & 146.01 & 145.87 \\
\hline Mean & 152.35 & 149.15 & 153.10 & \\
\hline $\mathrm{CD}(\mathrm{P}=0.05)$ & \multicolumn{4}{|c|}{ Spray Schedule $(\mathrm{S})=1.25$, Treatments $(\mathrm{T})=1.62, \mathrm{~S} x \mathrm{~T}=2.80$} \\
\hline
\end{tabular}

Table 2. Effect of foliar application of potassium and spray schedule on fruit diameter $(\mathrm{cm})$.

\begin{tabular}{lccc}
\hline Treatments & \multicolumn{3}{c}{ Spray schedule } \\
\cline { 2 - 4 } Mean & $\mathrm{S}_{1}$ & $\mathrm{~S}_{2}$ & 6.76 \\
\hline $\mathrm{T}_{1}: \mathrm{KNO}_{3} 2 \%$ & 6.65 & 6.44 & 6.62 \\
$\mathrm{~T}_{2}: \mathrm{KNO}_{3} 4 \%$ & 6.80 & 6.52 & 6.85 \\
$\mathrm{~T}_{3}: \mathrm{K}_{2} \mathrm{SO}_{4} 1.5 \%$ & 6.49 & 6.42 & 6.55 \\
$\mathrm{~T}_{4}: \mathrm{K}_{2} \mathrm{SO}_{4} 3 \%$ & 6.61 & 6.55 & 6.69 \\
$\mathrm{~T}_{5}:$ Control (water spray) & 6.37 & 6.32 & 6.42 \\
$\mathrm{Mean}$ & 6.58 & 6.45 & 6.37 \\
$\mathrm{CD}(\mathrm{P}=0.05)$ & Spray Schedule $(\mathrm{S})=0.08$, Treatments $(\mathrm{T})=0.09, \mathrm{~S} \times \mathrm{T}=0.16$ \\
\hline
\end{tabular}


Vijay et al. / J. Appl. \& Nat. Sci. 9 (2): 786 - 790 (2017)

Table 3(a). Effect of foliar application of potassium and spray schedule on percentage of small fruits.

\begin{tabular}{|c|c|c|c|c|}
\hline \multirow{2}{*}{ Treatments } & \multicolumn{3}{|c|}{ Spray schedule } & \multirow{2}{*}{ Mean } \\
\hline & $\mathrm{S}_{1}$ & $\mathrm{~S}_{2}$ & $\mathrm{~S}_{3}$ & \\
\hline $\mathrm{T}_{1}: \mathrm{KNO}_{3} 2 \%$ & 23.50 & 31.63 & 25.94 & 27.02 \\
\hline $\mathrm{T}_{2}: \mathrm{KNO}_{3} 4 \%$ & 15.37 & 22.24 & 13.85 & 17.15 \\
\hline $\mathrm{T}_{3}: \mathrm{K}_{2} \mathrm{SO}_{4} 1.5 \%$ & 31.04 & 34.84 & 29.39 & 31.76 \\
\hline $\mathrm{T}_{4}: \mathrm{K}_{2} \mathrm{SO}_{4} 3 \%$ & 24.12 & 29.35 & 24.41 & 25.96 \\
\hline $\mathrm{T}_{5}$ : Control (water spray) & 39.08 & 38.99 & 39.07 & 39.05 \\
\hline Mean & 26.62 & 31.41 & 26.53 & \\
\hline $\mathrm{CD}(\mathrm{P}=0.05)$ & \multicolumn{4}{|c|}{ Spray schedule $(\mathrm{S})=1.31$, Treatment $(\mathrm{T})=1.69, \mathrm{SxT}=2.92$} \\
\hline
\end{tabular}

Table 3(b). Effect of foliar application of potassium and spray schedule on percentage of medium fruits.

\begin{tabular}{lcccc}
\hline \multirow{2}{*}{ Treatments } & \multicolumn{3}{c}{ Spray schedule } & \multirow{2}{*}{ Mean } \\
\cline { 2 - 4 } & $\mathrm{S}_{1}$ & $\mathrm{~S}_{2}$ & $\mathrm{~S}_{3}$ & 59.72 \\
$\mathrm{~T}_{1}: \mathrm{KNO}_{3} 2 \%$ & 60.24 & 56.18 & 62.75 & 68.00 \\
$\mathrm{~T}_{2}: \mathrm{KNO}_{3} 4 \%$ & 69.56 & 64.02 & 70.43 & 57.27 \\
$\mathrm{~T}_{3}: \mathrm{K}_{2} \mathrm{SO}_{4} 1.5 \%$ & 57.65 & 54.85 & 59.32 & 61.05 \\
$\mathrm{~T}_{4}: \mathrm{K}_{2} \mathrm{SO}_{4} 3 \%$ & 62.18 & 58.37 & 62.60 & 51.33 \\
$\mathrm{~T}_{5}:$ Control (water spray) & 51.52 & 51.44 & 51.04 & \\
Mean & 60.23 & 56.97 & 61.23 & \\
$\mathrm{CD}(\mathrm{P}=0.05)$ & \multicolumn{2}{c}{ Spray schedule (SxT)=1.50, Treatment $(\mathrm{T})=1.93, \mathrm{SxT}=2.72$} \\
\hline
\end{tabular}

Table 3(c). Effect of foliar application of potassium and spray schedule on percentage of large fruits.

\begin{tabular}{|c|c|c|c|c|}
\hline \multirow{2}{*}{ Treatments } & \multicolumn{3}{|c|}{ Spray schedule } & \multirow{2}{*}{ Mean } \\
\hline & $\mathrm{S}_{1}$ & $\mathrm{~S}_{2}$ & $\mathrm{~S}_{3}$ & \\
\hline $\mathrm{T}_{1}: \mathrm{KNO}_{3} 2 \%$ & 15.46 & 12.19 & 11.31 & 12.99 \\
\hline $\mathrm{T}_{2}: \mathrm{KNO}_{3} 4 \%$ & 15.86 & 13.74 & 15.72 & 15.11 \\
\hline $\mathrm{T}_{3}: \mathrm{K}_{2} \mathrm{SO}_{4} 1.5 \%$ & 11.24 & 10.32 & 11.29 & 10.95 \\
\hline $\mathrm{T}_{4}: \mathrm{K}_{2} \mathrm{SO}_{4} 3 \%$ & 13.70 & 12.28 & 12.99 & 12.99 \\
\hline $\mathrm{T}_{5}$ : Control (water spray) & 9.40 & 9.58 & 9.89 & 9.62 \\
\hline Mean & 13.13 & 11.62 & 12.24 & \\
\hline $\mathrm{CD}(\mathrm{P}=0.05)$ & \multicolumn{4}{|c|}{ Spray schedule $(S)=0.83$, Treatment $(T)=1.07, \mathrm{SxT}=1.86$} \\
\hline
\end{tabular}

tions in Clementine citrus. Interaction effect of treatments and spraying schedule was also found significant. Maximum average fruit weight (159.81 g) was found with interaction of $\mathrm{KNO}_{3} @ 4 \%$ sprayed during the last week of April, May and August $\left(\mathrm{T}_{2} \times \mathrm{S}_{3}\right)$ which was statistically at par with two sprays of $\mathrm{KNO}_{3}$ (a) $4 \%$ during the last week of April and August $\left(\mathrm{T}_{2} \mathrm{x}\right.$ $\mathrm{S}_{1}$ ), however minimum average fruit weight (145.68 g) was recorded with interaction effect of two sprays of water (control) in the last week of April and August $\left(\mathrm{T}_{5} \times \mathrm{S}_{1}\right)$.

The results indicated that all the potassium treatments improved the fruit size i.e. fruit diameter and percentage of medium and large fruits over control (Table 2, 3 (a), 3(b) and 3(c) and there was an increase in fruit size with an increase in $\mathrm{K}$ doses of $\mathrm{KNO}_{3}$ and $\mathrm{K}_{2} \mathrm{SO}_{4}$, irrespective of spray schedule. Maximum fruit diameter $(6.72 \mathrm{~cm})$ and percentage of medium (68.00) and large (15.11) fruits was with foliar application of $\mathrm{KNO}_{3} @ 4$ $\%$. The percentage of medium sized fruits was higher as compared to large or small sized fruits in all treatments including control. Among the spray schedules two sprays during April and August and three sprays during April, May and August were found at par and significant over two sprays during May and August in improving fruit size (fruit diameter) as well as increasing the medium and large fruit percentage. This shows that early application of $\mathrm{K}$ (during end of April and August) helps in more improvement of fruit size as compared to delayed spray in May and August as the fruits has already attained more than $50 \%$ of its size. Interaction effect of treatments and spraying schedule was also found significant. Maximum fruit diameter $(6.85 \mathrm{~cm})$ was found with interaction of $\mathrm{KNO}_{3} @ 4 \%$ sprayed in the last week of April, May and August $\left(\mathrm{T}_{2}\right.$ $\left.\mathrm{x} \mathrm{S}_{3}\right)$ closely followed by $\left(\mathrm{T}_{2} \times \mathrm{S}_{1}\right)$. Minimum fruit diameter $(6.32 \mathrm{~cm})$ was recorded with interaction effect of two sprays of water (control) in the last week of May and August $\left(\mathrm{T}_{5} \times \mathrm{S}_{2}\right)$. Maximum small size fruits $(39.08 \%)$ were found with interaction of water (control) sprayed during the last week of April and August $\left(\mathrm{T}_{5} \times \mathrm{S}_{1}\right)$, however, minimum small size fruits $(13.85 \%)$ were recorded with interaction effect of three sprays of $\mathrm{KNO}_{3} @ 4 \%$ during the last week of April, May and August $\left(\mathrm{T}_{2} \times \mathrm{S}_{3}\right)$ which was statistically at par with $\left(\mathrm{T}_{2} \times \mathrm{S}_{1}\right)$. Maximum medium size fruits $(70.43 \%)$ were found with interaction of $\mathrm{KNO}_{3} @ 4$ $\%$ sprayed during the last week of April, May and August $\left(\mathrm{T}_{2} \times \mathrm{S}_{3}\right)$ followed by $\left(\mathrm{T}_{2} \times \mathrm{S}_{1}\right)$. Minimum medium size fruits $(51.04 \%)$ were recorded with inter- 
Vijay et al. / J. Appl. \& Nat. Sci. 9 (2): 786 - 790 (2017)

Table 4. Effect of foliar application of potassium and spray schedule on number of fruits/plant.

\begin{tabular}{lcccc}
\hline \multirow{2}{*}{ Treatments } & \multicolumn{3}{c}{ Spray schedule } & \multirow{2}{*}{ Mean } \\
\cline { 2 - 4 } & $\mathbf{S}_{\mathbf{1}}$ & $\mathbf{S}_{\mathbf{2}}$ & $\mathbf{S}_{\mathbf{3}}$ & 461.11 \\
$\mathrm{~T}_{1}: \mathrm{KNO}_{3} 2 \%$ & 464.33 & 451.33 & 467.67 & 478.22 \\
$\mathrm{~T}_{2}: \mathrm{KNO}_{3} 4 \%$ & 483.33 & 473.67 & 477.67 & 451.78 \\
$\mathrm{~T}_{3}: \mathrm{K}_{2} \mathrm{SO}_{4} 1.5 \%$ & 452.33 & 446.67 & 456.33 & 455.78 \\
$\mathrm{~T}_{4}: \mathrm{K}_{2} \mathrm{SO}_{4}$ 3\% & 454.33 & 456.00 & 457.00 & 446.67 \\
$\mathrm{~T}_{5}:$ Control (water spray) & 447.67 & 442.67 & 449.67 & \\
Mean & 460.4 & 454.07 & 461.67 \\
$\mathrm{CD}(\mathrm{P}=0.05)$ & Spray Schedule (S) = NS, Treatments (T)= NS, SxT=NS \\
\hline
\end{tabular}

Table 5. Effect of foliar application of potassium and spray schedule on yield (kg/plant).

\begin{tabular}{lcccc}
\hline \multirow{2}{*}{ Treatments } & \multicolumn{3}{c}{ Spray schedule } & \multirow{2}{*}{ Mean } \\
\cline { 2 - 4 } & $\mathbf{S}_{\mathbf{1}}$ & $\mathbf{S}_{\mathbf{2}}$ & $\mathbf{S}_{\mathbf{3}}$ & 70.50 \\
$\mathrm{~T}_{1}: \mathrm{KNO}_{3} 2 \%$ & 71.24 & 67.91 & 72.34 & 74.76 \\
$\mathrm{~T}_{2}: \mathrm{KNO}_{3} 4 \%$ & 76.90 & 71.05 & 76.32 & 67.60 \\
$\mathrm{~T}_{3}: \mathrm{K}_{2} \mathrm{SO}_{4} 1.5 \%$ & 67.88 & 66.12 & 68.79 & 69.74 \\
$\mathrm{~T}_{4}: \mathrm{K}_{2} \mathrm{SO}_{4} 3 \%$ & 69.71 & 69.05 & 70.47 & 65.16 \\
$\mathrm{~T}_{5}:$ Control (water spray) & 65.21 & 64.60 & 65.66 & \\
$\mathrm{Mean}$ & 70.19 & 67.75 & 70.72 & \\
$\mathrm{CD}(\mathrm{P}=0.05)$ & Spray Schedule $(\mathrm{S})=2.32$, Treatments $(\mathrm{T})=3.45, \mathrm{SxT}=5.62$ \\
\hline
\end{tabular}

action effect of three sprays of water (control) during the last week of April, May and August $\left(\mathrm{T}_{5} \times \mathrm{S}_{3}\right)$. Maximum large size fruits $(15.86 \%)$ were found with interaction of $\mathrm{KNO}_{3} @ 4 \%$ sprayed during the last week of April and August $\left(\mathrm{T}_{2} \times \mathrm{S}_{1}\right)$ closely followed by $\left(\mathrm{T}_{2} \times \mathrm{S}_{3}\right)$ and $\left(\mathrm{T}_{1} \times \mathrm{S}_{1}\right)$. Minimum large size fruits $(9.40 \%)$ were recorded with interaction effect of two sprays of water (control) during the last week of April and August $\left(\mathrm{T}_{5} \times \mathrm{S}_{1}\right)$. Likewise, Obreza et al. (2008) reported that increasing the rate and frequency of foliar application of $\mathrm{K}$ was accompanied by an increase in the size of florida citrus fruit. The increased fruit size might be due to the role of potassium in cell wall construction as observed in grape fruit plants (Boman and Hebb, 1998). Similar findings were observed with foliar application of $25 \mathrm{lb}$ /acre $\mathrm{KNO}_{3}$ at key times in Sunburst tangerine (Boman, 2002). Hamza et al. (2012) also observed that the treatment $8 \% \mathrm{KNO}_{3}$ (sprayed thrice) gave the best percentage of extra size class $(57-63 \mathrm{~mm})$ in citrus Clementine var. Cadoux. Sangwan et al. (2008) reported that maximum number of large sized fruit was observed with treatment $\mathrm{KNO}_{3}$ (a) $2 \%$ in Kinnow. Yadav et al. (2014) also reported a significant increase in fruit diameter with three sprays of $2 \% \mathrm{~K}_{2} \mathrm{SO}_{4}$ in ber fruits.

The number of fruits per plant was not significantly influenced by various potassium treatments and spray schedules (Table 4). However, numerically more fruits were obtained with various potassium treatments, which may be due to continuous supply of food to the developing fruits and this leads to decreased fruit drop. Effect on fruit yield: There was an increase in fruit yield with an increase in $\mathrm{K}$ doses of $\mathrm{KNO}_{3}$ and $\mathrm{K}_{2} \mathrm{SO}_{4}$, irrespective of spray schedule (Table 5). Maximum yield $(74.76 \mathrm{~kg})$ was recorded with $\mathrm{KNO}_{3} @ 4$
$\%$. Similarly, increased frequency of $\mathrm{K}$ sprays increased the yield. Maximum yield $(70.72 \mathrm{~kg}$ ) was observed with three sprays of potassium in the last week of April, May and August followed by two sprays during April and August. The increase in yield might be due to increase in fruit weight and improvement in plant vigor which increases the fruit reserves which serves the fruits till harvest and retaining somewhat more fruits as evident from the present investigation. Similar results were also observed by Sangwan et al. (2008) where they found maximum yield with $\mathrm{KNO}_{3}$ (a) $2 \%$ in Kinnow mandarin. Mostafa and Saleh (2006) reported that spraying potassium nitrate with girdling had a positive effect on fruit yield of Balady mandarin. Dutta et al. (2011) found similar results with foliar application of $\mathrm{K}_{2} \mathrm{SO}_{4} @ 1 \%$ in mango. Hamza et al. (2012) concluded that raising the $\mathrm{K}$ concentration and the number of foliar applications increased the fruit yield and best results were obtained with three foliar applications of $\mathrm{KNO}_{3} @ 8 \%$ in citrus Clementine fruits. Interaction effect of treatments and spraying schedule was also found significant. Maximum yield $(76.90 \mathrm{~kg} /$ tree $)$ was recorded with interaction of $\mathrm{KNO}_{3}$ (a) $4 \%$ sprayed during the last week of April and August $\left(\mathrm{T}_{2} \times \mathrm{S}_{1}\right)$ which was found at par with $\left(\begin{array}{lll}\mathrm{T}_{2} & \times \mathrm{S}_{3}\end{array}\right)$ and $\left(\mathrm{T}_{1} \times \mathrm{S}_{3}\right)$. Minimum yield $(64.60 \mathrm{~kg} /$ tree $)$ was recorded with interaction effect of two sprays of water (control) in the last week of May and August $\left(\mathrm{T}_{5} \times \mathrm{S}_{2}\right)$.

\section{Conclusion}

Citrus fruit is known as a rich source of dietary fibre and nutrients. The cultivation of citrus crop is gaining momentum in north western states of India. The present study infers that foliar application of $\mathrm{K}$ during reproductive stage of the crop is beneficial for improv- 
ing fruit yield and yield parameters. The fruit yield was recorded the highest $(76.90 \mathrm{~kg} / \mathrm{plant})$ with the foliar application of $\mathrm{KNO}_{3}$ at the rate of $4 \%$ sprayed twice in the last week of April and August, probably due to the highest percentage of large fruits $(15.86 \%)$ and maximum number of fruits/plant (483.33) in this treatment. Foliar application of $\mathrm{KNO}_{3}$ at lower dose (2\%) and $\mathrm{K}_{2} \mathrm{SO}_{4}$ at 1.5 and $2 \%$ was found significantly inferior in enhancing fruit yield but all these treatments were better than control (no spray of K). The results achieved in the present investigation suggest an opportunity for the farmers to diversify the existing crop sequences in north western India towards horticultural crops.

\section{REFERENCES}

Abd-Allah, A. S. E. (2006). Effect of spraying some macro and micro nutrients on fruit set, yield and fruit quality of Washington Navel orange trees. J. Applied Sci. Res., 2(11):1059-1063

Alva, A.K., Mattos, D.J., Paramasivam, S., Patil, B., Dou, H. and Sajwan, K.S. (2006). Potassium management for optimizing citrus production and quality. Int. J. Fruit Sci., 6:3-43

Anonymous, (2013). Package of Practices for Horticultural Crops and Products. Directorate of Publications, Haryana Agric. Univ., Hisar, India

Boman, B. J. and Hebb, J. W. (1998). Post bloom and summer foliar K effects on grapefruit size. Proc. Fla. State Hort. Soc., 111:128-135

Boman, B. J. (2002). $\mathrm{KNO}_{3}$ foliar application to 'Sunburst' tangerine. Proc. Fla. State Hort. Soc., 115:6-9

Dutta, P., Ahmed, B. and Kundu, S. (2011). Effect of different sources of potassium on yield, quality and leaf mineral content of mango in West Bengal. Better crops-South Asia, Pp. 16-18

Erner, Y., Kaplan, B., Artzi, B. and Hamu, M. (1993). Increasing citrus fruit size using auxins and potassium. Acta Hort., 329:112-116

Hamza, A., Bamouh, A., Guilli, M. El. and Bouabid, R. (2012). Response of Clementine citrus var. Cadoux to foliar potassium fertilization; Effects on fruit production and quality. e-ifc, No. 31, Pp:8-15

Harold, J. E. and George, J. S. (1966). Role of mineral elements with emphasis on the univalent cations. Ann. Pl. Physiol., 11:47-76

Josan, J. S., Sandhu, A. S., Singh, R. and Monga, P. K. (1995). Effect of various nutrient sprays on fruit quality of lemon. Indian J. Hort., 52:288-290

Miller, J. E. and Hoffman, P. J. (1988). Physiology and nutrition of citrus fruit, growth with special reference to Valencia. A mini-review. Proc. $6^{\text {th }}$ Int. Citrus Cong., Tel Aviv, Pp. 503-510

Mostafa, E. A. M. and Saleh, M. M. S. (2006). Response of Balady mandarin trees to girdling and potassium sprays under sandy soil conditions. Res. J. Agric. and Biol. Sci., 2(3):137-141

Obreza, T. A., Morgan, K. T., Albrigo, L. G. and Boman, B. J. (2008). Recommended fertilizer rates and timing. In: Nutrition of Florida citrus trees. $2^{\text {nd }}$ ed. edited by T.A. Obreza and K.T. Morgan.

Panse, V. G. and Sukhatme, P. V. (1967). Statistical methods for agricultural workers. $2^{\text {nd }}$ ed. ICAR Publication, New Delhi, pp:336-356

Rattanpal, H. S., Rani, Shobha, Kumar, A. and Dhaliwal, H. S. (2005). Effect of potassium and 2,4-D sprays onphysical parameters of Kinnow fruits. Haryana J. Hort. Sci., 34(3-4):222-223

Sangwan, A. K., Rattanpal, H. S., Arora, N. K. and Dalal, R. S. (2008). Effect of foliar application of potassium on fruit yield and quality of Kinnow mandarin. Environ. Ecol., 26(4C):2315-2318

Saxena, M. and Gandhi, C. P. (2014). Indian Horticulture Database, National Horticulture Board, Ministry of Agri. Government of India, India.

Vijay, Dalal, R. P. S., Beniwal, B. S. and Saini, H. (2016). Impact of foliar application of potassium and its spray schedule on yield and quality of sweet orange (Citrus sinensis) cv. Jaffa. J. Applied Natural Sci., 8(4): 18931898

Yadav, D., Singh, S. P. and Singh, S. (2014). Effect of foliar application of potassium compounds on yield andquality of ber (Zizyphusmauritiana) cv. Banarasi Karaka. Int . J. Res. Applied Natural and social sci., 2:89-92 